\title{
The Caddo Ceramic Vessels from the Cemetery at 41HS74 on Hatley Creek in the Sabine River Basin, Harrison County, Texas
}

Timothy K. Perttula

Heritage Research Center, Stephen F. Austin State University

Follow this and additional works at: https://scholarworks.sfasu.edu/ita

Part of the American Material Culture Commons, Archaeological Anthropology Commons, Environmental Studies Commons, Other American Studies Commons, Other Arts and Humanities Commons, Other History of Art, Architecture, and Archaeology Commons, and the United States History Commons

Tell us how this article helped you.

This Article is brought to you for free and open access by the Center for Regional Heritage Research at SFA ScholarWorks. It has been accepted for inclusion in Index of Texas Archaeology: Open Access Gray Literature from the Lone Star State by an authorized editor of SFA ScholarWorks. For more information, please contact cdsscholarworks@sfasu.edu. 
The Caddo Ceramic Vessels from the Cemetery at 41HS74 on Hatley Creek in the Sabine River Basin, Harrison County, Texas

\section{Creative Commons License}

\section{(c) (1) \&}

This work is licensed under a Creative Commons Attribution-NonCommercial 4.0 International License 


\title{
The Caddo Ceramic Vessels from the Cemetery at 41 HS74 on Hatley Creek in the Sabine River Basin, Harrison County, Texas
}

\author{
Timothy K. Perttula
}

\section{Introduction}

Site 41HS74 is an ancestral Caddo habitation site and cemetery on Hatley Creek, a southwardwing tributary to the Sabine River, in the East Texas Pineywoods (Figure 1). The site was vestigated in 1986 by Heartfield, Price and Greene, Inc. (1988). The re-analysis of the ceramic vessels covered from nine burial features at the site are the subject of this article. The vessels are curated at e Texas Archeological Research Laboratory at The University of Texas at Austin (TARL).

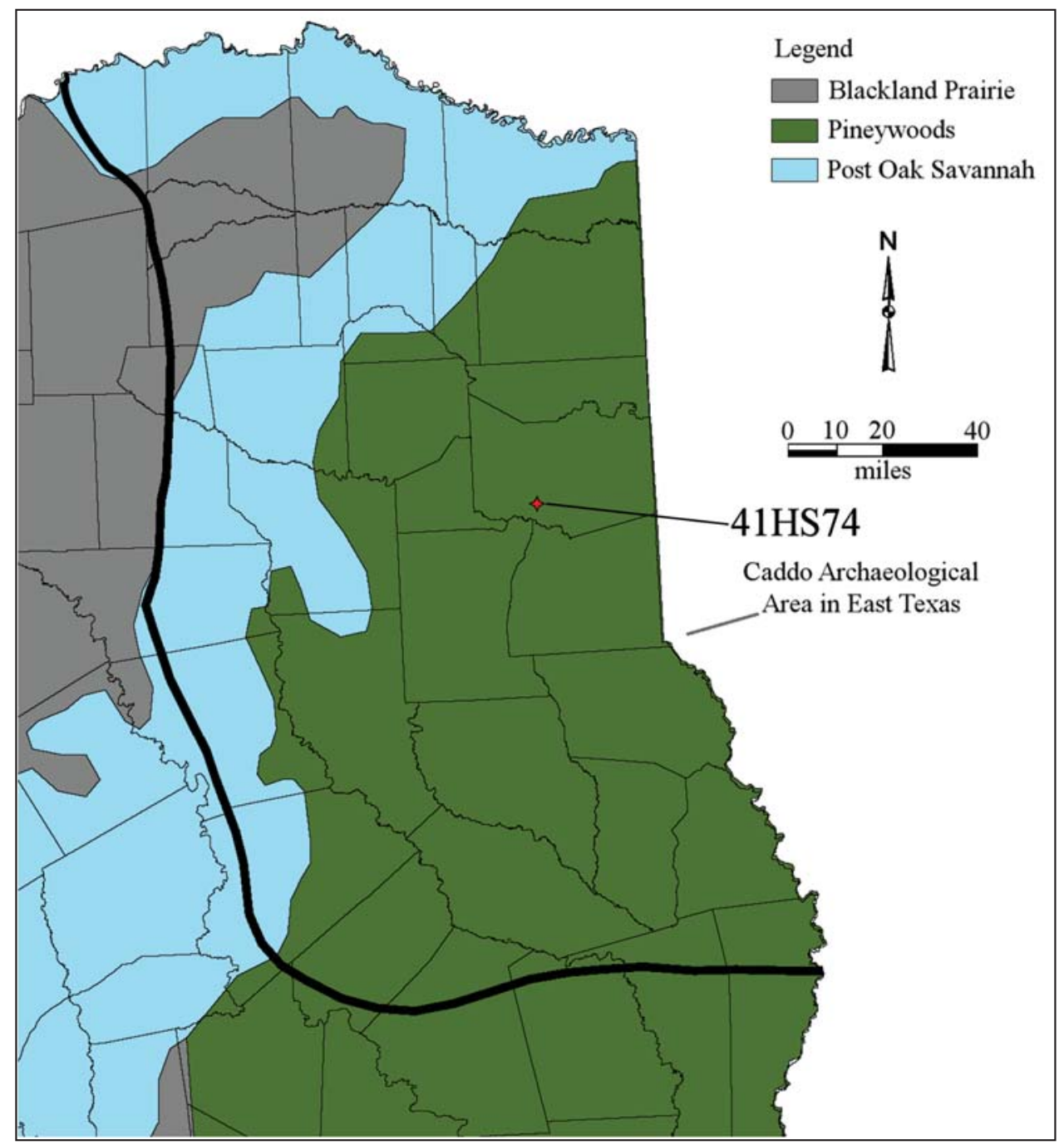

gure 1. General location of 41HS74 in East Texas. 


\section{Cemetery Features}

The excavations at 41HS74 included several backhoe trenches and grader trenches across the site, as well as the completion of major hand excavated blocks in three different, but roughly contiguous areas. This work identified northern and southern habitation areas with considerable artifact densities, an intermediate midden deposit, and a cemetery area not far to the west of those deposits (Figure 2a).

The cemetery area at 41HS74 covered a ca. $7 \times 6 \mathrm{~m}$ area and had nine burial features arranged in three or four east-west rows (see Figure 2b). Although the human skeletal remains were poorly preserved in the graves, their position as well as the orientation of the defined burial pit outlines indicates that the burials were laid out in an extended supine position with the deceased's head at the southern end of the burial pit and the burial pits themselves were oriented in a north-northwest direction; the burial features at the nearby Pine Tree Mound site are also oriented in the same direction (see Fields and Gadus 2012a, 2012b). Associated funerary offerings in the nine burial features include 25 ceramic vessels ( 2.8 vessels per burial, with a range of 1-4 vessels per burial), two ground stone tools (in Burials 1 and 5,0.2 ground stone per burial), and seven Bonham arrow points (Heartfield, Price and Greene, Inc. 1988:Table 7-1) found in a cache or quiver in Burial 9.

\section{Ceramic Vessels}

The re-analysis of the ceramic vessels from burial features at 41HS74 concerns 23 vessels. Two vessels (P.S. B and P.S. C) from Burial 8 were stolen from the site during the work, and are not in the TARL collections. The missing vessels from Burial 8 are described as a Canton Incised jar and a miniature pinched jar (Heartfield, Price and Greene, Inc. 1988:4-30).

SITE NAME OR SITE NUMBER: 41HS74

VESSEL NO.: Lot 1598, Burial 1

VESSEL FORM: Bowl

NON-PLASTICS AND PASTE: grog

RIM AND LIP FORM: Direct rim and rounded lip

CORE COLOR: F (fired in a reducing environment and cooled in the open air)

INTERIOR SURFACE COLOR: yellowish-brown; fire clouds on the rim, body, and base

EXTERIOR SURFACE COLOR: yellowish-brown; fire clouds on the body

WALL THICKNESS (IN MM): rim, $8.2 \mathrm{~mm}$

INTERIOR SURFACE TREATMENT: smoothed

EXTERIOR SURFACE TREATMENT: smoothed

HEIGHT (IN CM): 11.5

ORIFICE DIAMETER (IN CM): 12.3

DIAMETER AT BOTTOM OF RIM OR NECK (IN CM): 12.3 

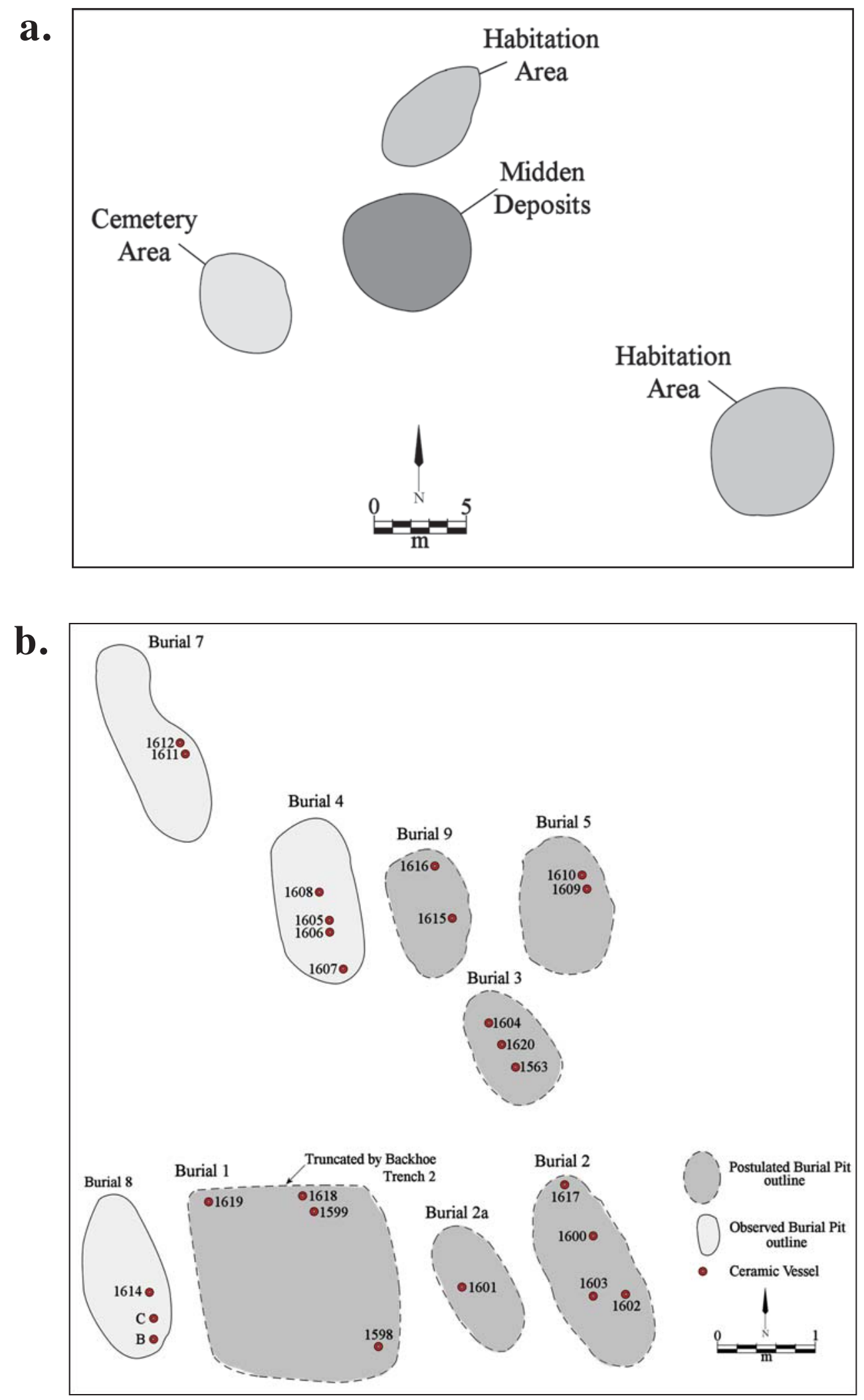

Figure 2. 41HS74 layout: a, habitation areas and cemetery area explored during data recovery; b, cemetery features at 41HS74, and placement of ceramic vessels in the different burials. 
BASE DIAMETER (IN CM) AND SHAPE OF BASE: 7.6

ESTIMATED VOLUME (IN LITERS): 0.56

DECORATION (INCLUDING MOTIF AND ELEMENTS WHEN APPARENT): The decorated panel, $60 \mathrm{~mm}$ in height, is comprised of five sets of upper and lower incised triangles filled with rows of tool punctations (Figure 3).

PIGMENT USE AND LOCATION ON VESSEL: none

TYPE AND VARIETY (IF KNOWN): Maydelle Incised

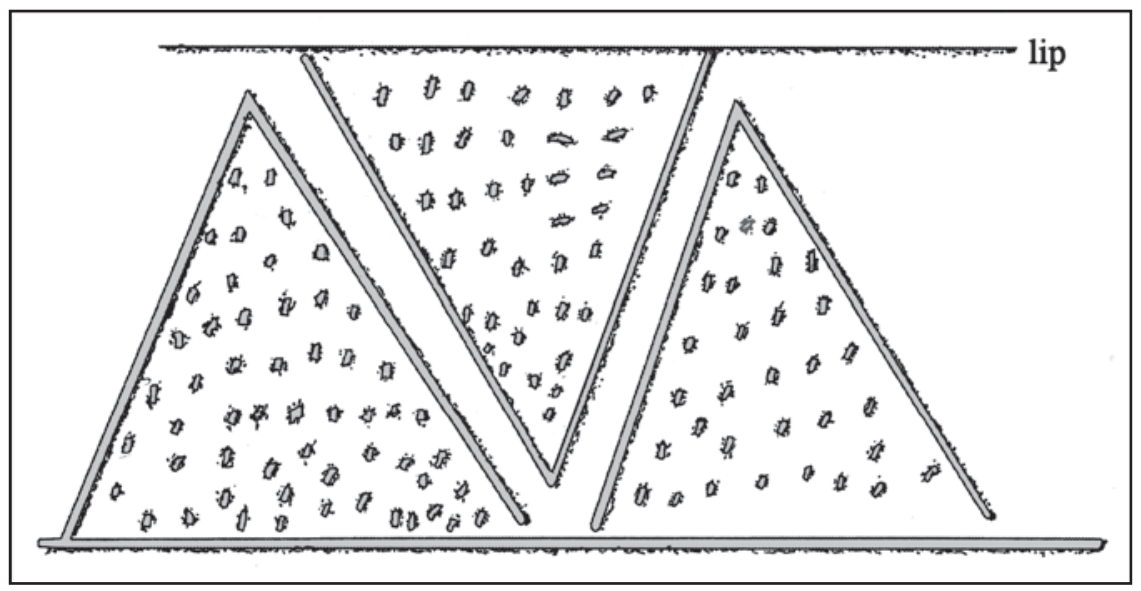

Figure 3. Maydelle Incised jar (Lot 1598) in Burial 1 at 41HS74.

SITE NAME OR SITE NUMBER: 41HS74

VESSEL NO.: Lot 1599, Burial 1

VESSEL FORM: Bottle

NON-PLASTICS AND PASTE: grog

RIM AND LIP FORM: N/A

CORE COLOR: $\mathrm{G}$ (fired in a reducing environment and cooled in the open air)

INTERIOR SURFACE COLOR: grayish-brown

EXTERIOR SURFACE COLOR: yellowish-brown; fire clouds on the body

WALL THICKNESS (IN MM): neck, 6.0 mm; body, $6.1 \mathrm{~mm}$

INTERIOR SURFACE TREATMENT: none

EXTERIOR SURFACE TREATMENT: burnished

HEIGHT (IN CM): 10.8+ 
ORIFICE DIAMETER (IN CM): 5.4

DIAMETER AT BOTTOM OF RIM OR NECK (IN CM): N/A

BASE DIAMETER (IN CM) AND SHAPE OF BASE: 7.6; circular and flat

ESTIMATED VOLUME (IN LITERS): 0.33+

DECORATION (INCLUDING MOTIF AND ELEMENTS WHEN APPARENT): Plain

PIGMENT USE AND LOCATION ON VESSEL: none

TYPE AND VARIETY (IF KNOWN): Unidentified plain ware

SITE NAME OR SITE NUMBER: 41HS74

VESSEL NO.: Lot 1618, Burial 1

VESSEL FORM: Jar

NON-PLASTICS AND PASTE: grog

RIM AND LIP FORM: N/A

CORE COLOR: $\mathrm{F}$ (fired in a reducing environment and cooled in the open air)

INTERIOR SURFACE COLOR: dark reddish-brown; fire clouds on the body

EXTERIOR SURFACE COLOR: yellowish-brown; fire clouds on the body and base

WALL THICKNESS (IN MM): body, $6.7 \mathrm{~mm}$; base, $8.0 \mathrm{~mm}$

INTERIOR SURFACE TREATMENT: none

EXTERIOR SURFACE TREATMENT: none

HEIGHT (IN CM): N/A

ORIFICE DIAMETER (IN CM): N/A

DIAMETER AT BOTTOM OF RIM OR NECK (IN CM): N/A

BASE DIAMETER (IN CM) AND SHAPE OF BASE: 9.6; circular and flat

ESTIMATED VOLUME (IN LITERS): N/A

DECORATION (INCLUDING MOTIF AND ELEMENTS WHEN APPARENT): The vessel body has vertical brushing marks and vertical tool punctated rows pushed through the brushing.

PIGMENT USE AND LOCATION ON VESSEL: none

TYPE AND VARIETY (IF KNOWN): Pease Brushed-Incised 
SITE NAME OR SITE NUMBER: 41HS74

VESSEL NO.: Lot 1619, Burial 1

VESSEL FORM: Bowl or Carinated bowl section (body and base of vessel only)

NON-PLASTICS AND PASTE: grog

RIM AND LIP FORM: N/A

CORE COLOR: $\mathrm{G}$ (fired in a reducing environment and cooled in the open air)

INTERIOR SURFACE COLOR: very dark gray

EXTERIOR SURFACE COLOR: brown; fire clouds on the body and base

WALL THICKNESS (IN MM): body, $5.4 \mathrm{~mm}$; base, $6.6 \mathrm{~mm}$

INTERIOR SURFACE TREATMENT: smoothed

EXTERIOR SURFACE TREATMENT: smoothed

HEIGHT (IN CM): N/A

ORIFICE DIAMETER (IN CM): N/A

DIAMETER AT BOTTOM OF RIM OR NECK (IN CM): N/A

BASE DIAMETER (IN CM) AND SHAPE OF BASE: 10.2; circular and flat

ESTIMATED VOLUME (IN LITERS): N/A

DECORATION (INCLUDING MOTIF AND ELEMENTS WHEN APPARENT): Plain

PIGMENT USE AND LOCATION ON VESSEL: none

TYPE AND VARIETY (IF KNOWN): Unidentified plain ware

SITE NAME OR SITE NUMBER: 41HS74

VESSEL NO.: Lot 1600, Burial 2

VESSEL FORM: Jar

NON-PLASTICS AND PASTE: bone

RIM AND LIP FORM: Direct rim and rounded, exterior flattened lip

CORE COLOR: $\mathrm{H}$ (fired in a reducing environment and cooled in the open air)

INTERIOR SURFACE COLOR: reddish-brown; fire clouds on the rim

EXTERIOR SURFACE COLOR: very dark grayish-brown 
WALL THICKNESS (IN MM): rim, $5.4 \mathrm{~mm}$; body, $6.4 \mathrm{~mm}$

INTERIOR SURFACE TREATMENT: smoothed

EXTERIOR SURFACE TREATMENT: none

HEIGHT (IN CM): 7.7

ORIFICE DIAMETER (IN CM): 9.4

DIAMETER AT BOTTOM OF RIM OR NECK (IN CM): 9.2

BASE DIAMETER (IN CM) AND SHAPE OF BASE: 5.4; circular and flat

ESTIMATED VOLUME (IN LITERS): 0.43

DECORATION (INCLUDING MOTIF AND ELEMENTS WHEN APPARENT): There is a single tool punctated row beneath the lip of the vessel. The vessel body has a series of 19 vertical appliqued ridges or fillets that extend from the rim-body juncture to the vessel base.

PIGMENT USE AND LOCATION ON VESSEL: none

TYPE AND VARIETY (IF KNOWN): Unidentified utility ware

SITE NAME OR SITE NUMBER: 41HS74

VESSEL NO.: Lot 1602, Burial 2

VESSEL FORM: Jar

NON-PLASTICS AND PASTE: grog

RIM AND LIP FORM: N/A

CORE COLOR: $\mathrm{H}$ (fired in a reducing environment and cooled in the open air)

INTERIOR SURFACE COLOR: yellowish-gray

EXTERIOR SURFACE COLOR: dark gray

WALL THICKNESS (IN MM): body, $8.9 \mathrm{~mm}$

INTERIOR SURFACE TREATMENT: none

EXTERIOR SURFACE TREATMENT: none

HEIGHT (IN CM): N/A

ORIFICE DIAMETER (IN CM): 8.2

DIAMETER AT BOTTOM OF RIM OR NECK (IN CM): N/A

BASE DIAMETER (IN CM) AND SHAPE OF BASE: 7.0; circular and flat 
ESTIMATED VOLUME (IN LITERS): N/A

DECORATION (INCLUDING MOTIF AND ELEMENTS WHEN APPARENT): Plain

PIGMENT USE AND LOCATION ON VESSEL: none

TYPE AND VARIETY (IF KNOWN): Unidentified plain ware

SITE NAME OR SITE NUMBER: 41HS74

VESSEL NO.: Lot 1603, Burial 2

VESSEL FORM: Carinated bowl

NON-PLASTICS AND PASTE: grog

RIM AND LIP FORM: N/A

CORE COLOR: $\mathrm{G}$ (fired in a reducing environment and cooled in the open air)

INTERIOR SURFACE COLOR: dark gray to dark yellowish-brown; fire clouds on the base

EXTERIOR SURFACE COLOR: dark gray to dark yellowish-brown; fire clouds on the base

WALL THICKNESS (IN MM): lower rim, $6.5 \mathrm{~mm}$; body, $8.2 \mathrm{~mm}$; base, $11.1 \mathrm{~mm}$

INTERIOR SURFACE TREATMENT: smoothed

EXTERIOR SURFACE TREATMENT: smoothed

HEIGHT (IN CM): N/A

ORIFICE DIAMETER (IN CM): 15.6

DIAMETER AT BOTTOM OF RIM OR NECK (IN CM): 15.6

BASE DIAMETER (IN CM) AND SHAPE OF BASE: N/A

ESTIMATED VOLUME (IN LITERS): N?A

DECORATION (INCLUDING MOTIF AND ELEMENTS WHEN APPARENT): There are at least two rows of small excised punctations on the lower part of the rim.

PIGMENT USE AND LOCATION ON VESSEL: none

TYPE AND VARIETY (IF KNOWN): possible Handy Engraved (see Suhm and Jelks 1962:63 and Plate 32)

SITE NAME OR SITE NUMBER: 41HS74

VESSEL NO.: Lot 1617, Burial 2

VESSEL FORM: Compound bowl 
NON-PLASTICS AND PASTE: grog

RIM AND LIP FORM: Everted rim and rounded lip

CORE COLOR: F (fired in a reducing environment and cooled in the open air)

INTERIOR SURFACE COLOR: yellowish-brown; fire clouds on the rim and base

EXTERIOR SURFACE COLOR: yellowish-brown; fire clouds on the rim, body, and base

WALL THICKNESS (IN MM): rim, $6.0 \mathrm{~mm}$; body, $6.2 \mathrm{~mm}$

INTERIOR SURFACE TREATMENT: none

EXTERIOR SURFACE TREATMENT: none

HEIGHT (IN CM): 11.4

ORIFICE DIAMETER (IN CM): 15.3

DIAMETER AT BOTTOM OF RIM OR NECK (IN CM): 14.8

BASE DIAMETER (IN CM) AND SHAPE OF BASE: 6.4; circular and rounded

ESTIMATED VOLUME (IN LITERS): 1.4

DECORATION (INCLUDING MOTIF AND ELEMENTS WHEN APPARENT): The upper panel is undecorated. The lower panel has an incised slanting scroll with a central incised circle (Figure 4) that is repeated four times around the vessel; the central incised circle is filled with tool punctates. Upper and lower scroll fill zones are also filled with tool punctates.

PIGMENT USE AND LOCATION ON VESSEL: none

TYPE AND VARIETY (IF KNOWN): Crockett Curvilinear Incised

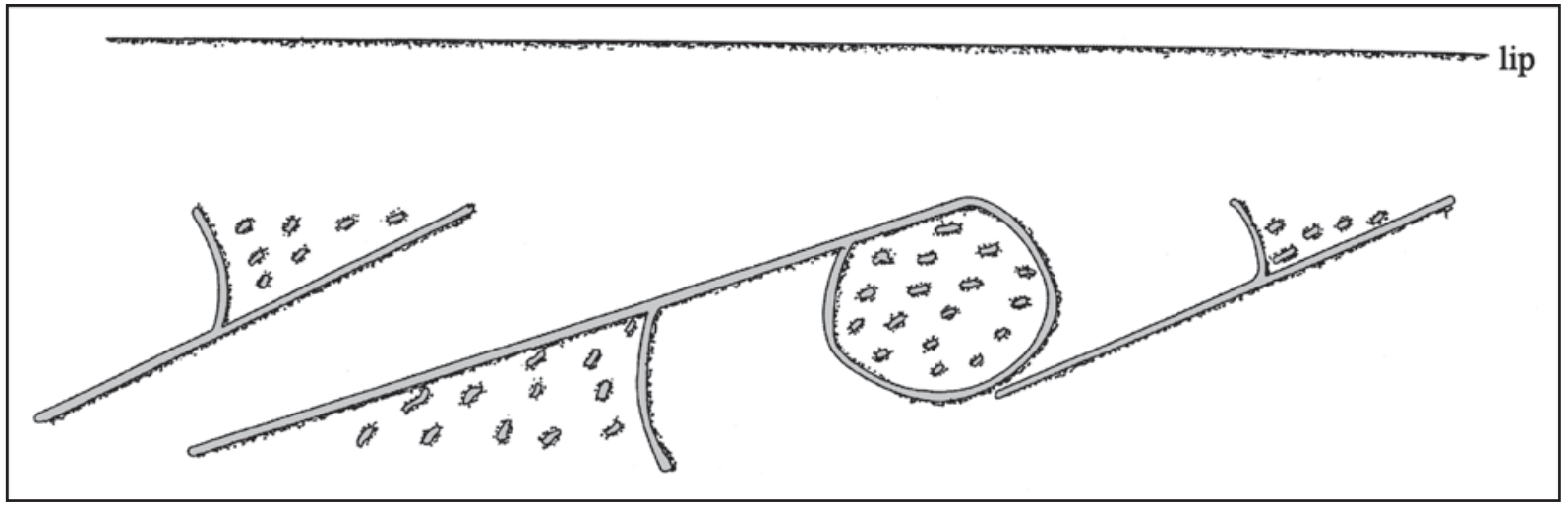

Figure 4. Decorative elements on Crockett Curvilinear Incised compound bowl (Burial 2) at 41HS74. 
SITE NAME OR SITE NUMBER: 41HS74

VESSEL NO.: Lot 1601, Burial 2A

VESSEL FORM: Compound bowl

NON-PLASTICS AND PASTE: grog

RIM AND LIP FORM: Direct rim and rounded lip

CORE COLOR: $\mathrm{F}$ (fired in a reducing environment and cooled in the open air)

INTERIOR SURFACE COLOR: yellowish-brown; fire clouds on the base

EXTERIOR SURFACE COLOR: yellowish-brown; fire clouds on the body and base

WALL THICKNESS (IN MM): rim, $6.6 \mathrm{~mm}$; body, $7.3 \mathrm{~mm}$; base, $12.2 \mathrm{~mm}$

INTERIOR SURFACE TREATMENT: smoothed

EXTERIOR SURFACE TREATMENT: smoothed

HEIGHT (IN CM): 7.3

ORIFICE DIAMETER (IN CM): 14.5

DIAMETER AT BOTTOM OF RIM OR NECK (IN CM): 14.7

BASE DIAMETER (IN CM) AND SHAPE OF BASE: 7.6; circular and flat

ESTIMATED VOLUME (IN LITERS): 0.85

DECORATION (INCLUDING MOTIF AND ELEMENTS WHEN APPARENT): The upper panel of the vessel has three widely-spaced horizontal engraved lines (Figure 5). The lower panel has six repeating sets of two horizontal-vertical scroll lines.

PIGMENT USE AND LOCATION ON VESSEL: none

TYPE AND VARIETY (IF KNOWN): Unidentified fine ware

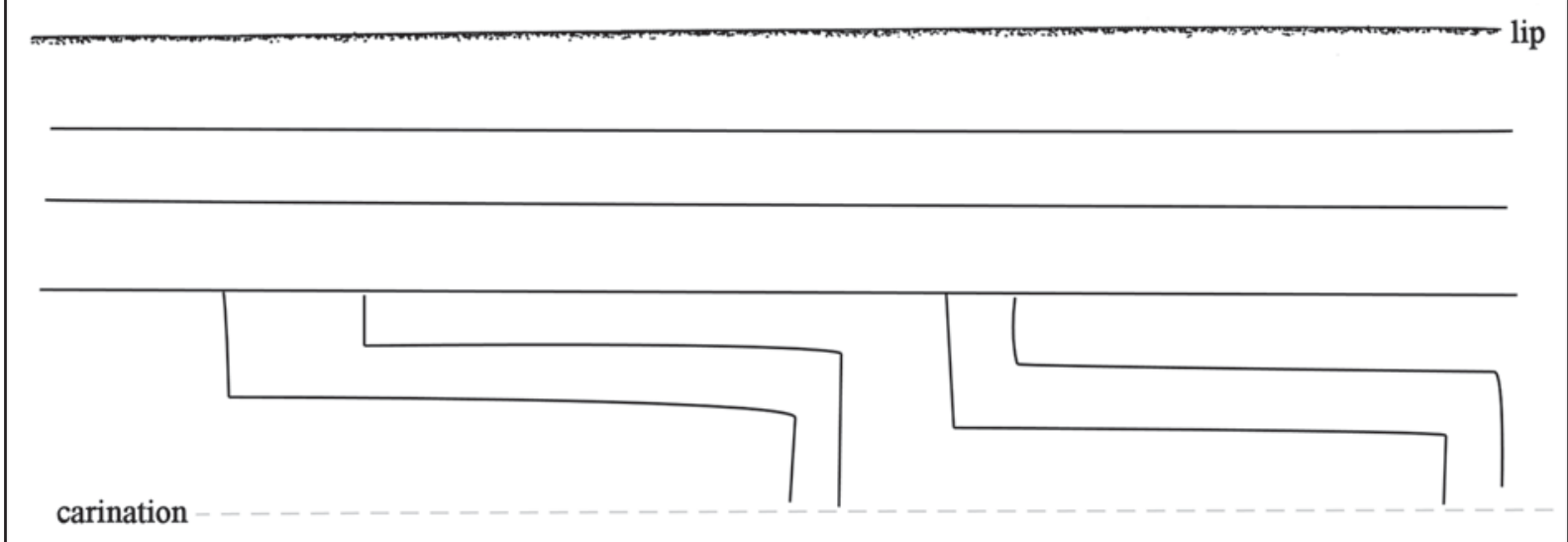

Figure 5. Decorative elements on compound bowl (Lot 1601) from Burial 2A at 41HS74. 
SITE NAME OR SITE NUMBER: 41HS74

VESSEL NO.: Lot 1563, Burial 3

VESSEL FORM: Bowl

NON-PLASTICS AND PASTE: grog

RIM AND LIP FORM: Direct rim and rounded lip

CORE COLOR: $\mathrm{F}$ (fired in a reducing environment and cooled in the open air)

INTERIOR SURFACE COLOR: dark yellowish-brown

EXTERIOR SURFACE COLOR: yellowish-brown; fire clouds on the base

WALL THICKNESS (IN MM): rim, $5.5 \mathrm{~mm}$

INTERIOR SURFACE TREATMENT: none

EXTERIOR SURFACE TREATMENT: none

HEIGHT (IN CM): 6.2

ORIFICE DIAMETER (IN CM): 8.9

DIAMETER AT BOTTOM OF RIM OR NECK (IN CM): N/A

BASE DIAMETER (IN CM) AND SHAPE OF BASE: 6.4; circular and rounded

ESTIMATED VOLUME (IN LITERS): 0.22

DECORATION (INCLUDING MOTIF AND ELEMENTS WHEN APPARENT): The exterior vessel surface is covered with a series of circular appliqued nodes.

PIGMENT USE AND LOCATION ON VESSEL: none

TYPE AND VARIETY (IF KNOWN): cf. Moore Noded (see Webb 1959:Figure 122a)

SITE NAME OR SITE NUMBER: 41HS74

VESSEL NO.: Lot 1604, Burial 3

VESSEL FORM: Carinated bowl

NON-PLASTICS AND PASTE: grog

RIM AND LIP FORM: Direct rim and a rounded, exterior folded lip

CORE COLOR: B (fired and cooled in a reducing environment)

INTERIOR SURFACE COLOR: very dark grayish-brown 
EXTERIOR SURFACE COLOR: very dark grayish-brown

WALL THICKNESS (IN MM): rim, $5.4 \mathrm{~mm}$; body, $5.9 \mathrm{~mm}$; base, $6.1 \mathrm{~mm}$

INTERIOR SURFACE TREATMENT: smoothed

EXTERIOR SURFACE TREATMENT: smoothed

HEIGHT (IN CM): 6.4

ORIFICE DIAMETER (IN CM): 15.3

DIAMETER AT BOTTOM OF RIM OR NECK (IN CM): 15.3

BASE DIAMETER (IN CM) AND SHAPE OF BASE: 10.8; circular and rounded

ESTIMATED VOLUME (IN LITERS): 0.59

DECORATION (INCLUDING MOTIF AND ELEMENTS WHEN APPARENT): The rim has four broadly-spaced horizontal incised lines above a panel with one or two curvilinear rows of circular punctations (Figure 6).

PIGMENT USE AND LOCATION ON VESSEL: none

TYPE AND VARIETY (IF KNOWN): Unidentified incised-punctated

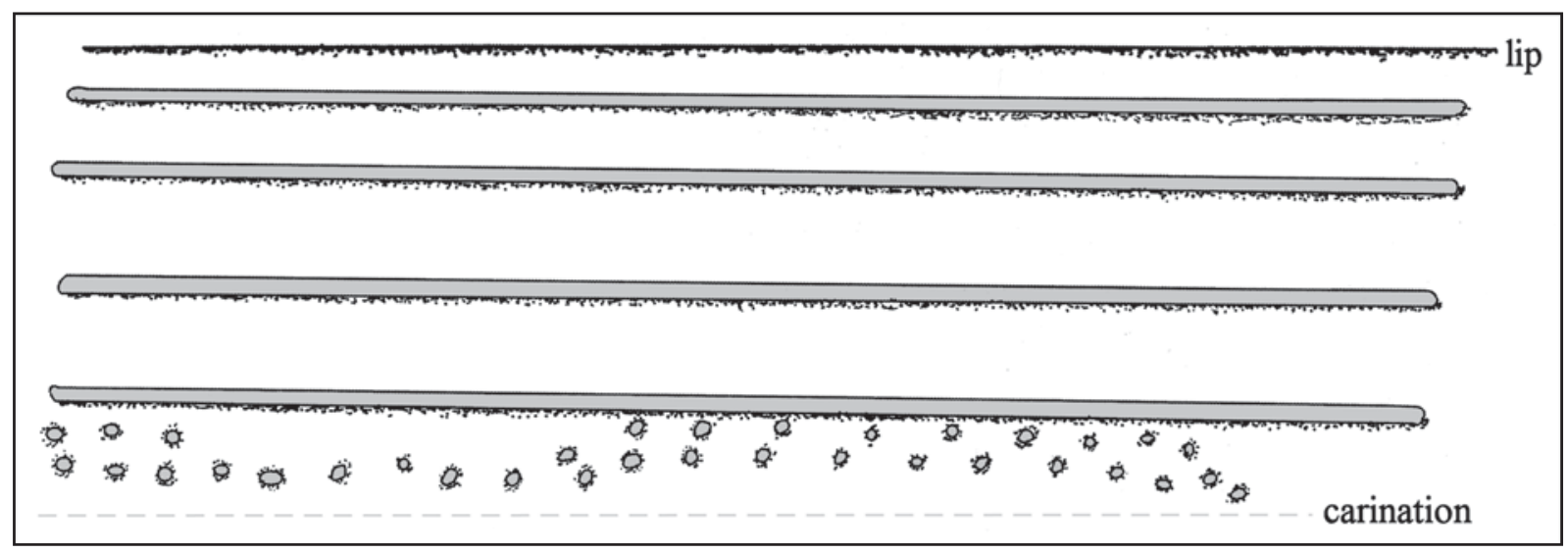

Figure 6. Incised-punctated carinated bowl (Lot 1604) from Burial 3 at 41HS74.

SITE NAME OR SITE NUMBER: 41HS74

VESSEL NO.: Lot 1620, Burial 3

VESSEL FORM: Carinated bowl

NON-PLASTICS AND PASTE: grog

RIM AND LIP FORM: Direct rim and rounded, exterior folded lip

CORE COLOR: $\mathrm{G}$ (fired in a reducing environment and cooled in the open air) 
INTERIOR SURFACE COLOR: dark gray

EXTERIOR SURFACE COLOR: yellowish-brown; fire clouds on the rim and body

WALL THICKNESS (IN MM): rim, $5.5 \mathrm{~mm}$; body, $7.1 \mathrm{~mm}$

INTERIOR SURFACE TREATMENT: none

EXTERIOR SURFACE TREATMENT: smoothed

HEIGHT (IN CM): N/A

ORIFICE DIAMETER (IN CM): 12.5

DIAMETER AT BOTTOM OF RIM OR NECK (IN CM): 12.5

BASE DIAMETER (IN CM) AND SHAPE OF BASE: N/A

ESTIMATED VOLUME (IN LITERS): N/A

DECORATION (INCLUDING MOTIF AND ELEMENTS WHEN APPARENT): Plain

PIGMENT USE AND LOCATION ON VESSEL: none

TYPE AND VARIETY (IF KNOWN): Unidentified plain ware

SITE NAME OR SITE NUMBER: 41HS74

VESSEL NO.: Lot 1605, Burial 4

VESSEL FORM: Bottle

NON-PLASTICS AND PASTE: grog

RIM AND LIP FORM: Direct rim and rounded lip

CORE COLOR: $\mathrm{G}$ (fired in a reducing environment and cooled in the open air)

INTERIOR SURFACE COLOR: grayish-brown

EXTERIOR SURFACE COLOR: yellowish-brown; fire clouds on the body and base

WALL THICKNESS (IN MM): rim, 7.4 mm

INTERIOR SURFACE TREATMENT: none

EXTERIOR SURFACE TREATMENT: none

HEIGHT (IN CM): 16.4

ORIFICE DIAMETER (IN CM): 3.8

DIAMETER AT BOTTOM OF RIM OR NECK (IN CM): 5.0 
BASE DIAMETER (IN CM) AND SHAPE OF BASE: 6.4; circular and flat

ESTIMATED VOLUME (IN LITERS): 0.42

DECORATION (INCLUDING MOTIF AND ELEMENTS WHEN APPARENT): The vessel body has a series of broad curvilinear engraved zones filled with diagonal hatched lines (Figure 7). These zones wrap around a circular element repeated twice on the vessel. Within the circular element is another curvilinear engraved line that ends in a small hatched engraved circle.

PIGMENT USE AND LOCATION ON VESSEL: none

TYPE AND VARIETY (IF KNOWN): This vessel from Burial 4 was originally identified as an engraved bottle with a possible rattlesnake motif (Heartfield, Price and Greene, Inc. 1988:Figure 6-15), possibly one of a number of vessels (some subsumed under the Nacogdoches Engraved rubric) found in Middle and Late Caddo period East Texas sites with engraved rattlesnake motifs (see Hart 2014; Hart and Perttula 2010; Walters 2006). Re-examination of the engraved elements on this bottle suggest instead that it is an unidentified fine ware vessel with curvilinear hatched zones and a central hatched circle (Figure 7).

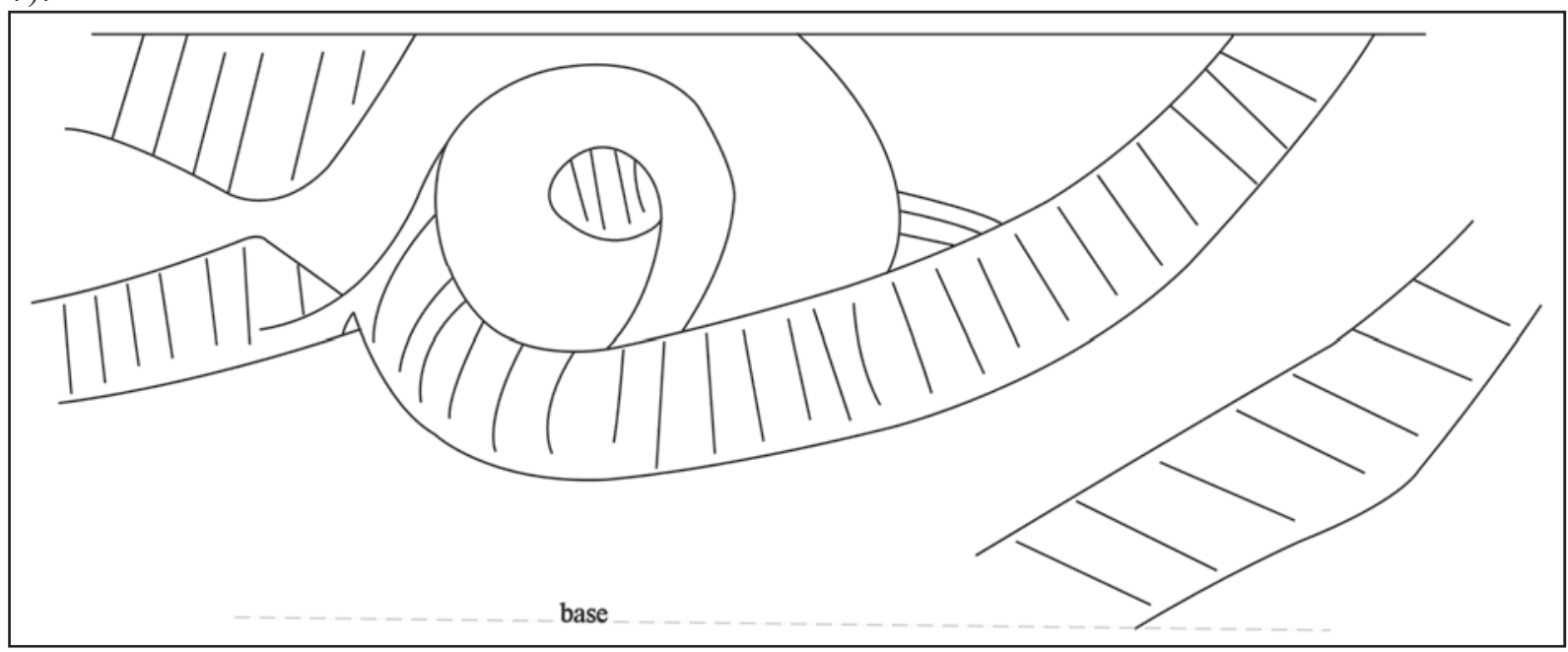

Figure 7. Decorative elements on the engraved bottle (Lot 1605) from Burial 4 at 41HS74.

SITE NAME OR SITE NUMBER: 41HS74

VESSEL NO.: Lot 1606, Burial 4

VESSEL FORM: Jar

NON-PLASTICS AND PASTE: grog

RIM AND LIP FORM: Direct rim and rounded lip

CORE COLOR: F (fired in a reducing environment and cooled in the open air)

INTERIOR SURFACE COLOR: reddish-brown; fire clouds on the base

EXTERIOR SURFACE COLOR: reddish-brown; fire clouds on the body and base 
WALL THICKNESS (IN MM): rim, $8.0 \mathrm{~mm}$

INTERIOR SURFACE TREATMENT: none

EXTERIOR SURFACE TREATMENT: none

HEIGHT (IN CM): 10.2

ORIFICE DIAMETER (IN CM): 9.3

DIAMETER AT BOTTOM OF RIM OR NECK (IN CM): 9.3

BASE DIAMETER (IN CM) AND SHAPE OF BASE: 6.2; circular and flat

ESTIMATED VOLUME (IN LITERS): 0.57

DECORATION (INCLUDING MOTIF AND ELEMENTS WHEN APPARENT): Vertical brushing marks on the rim and body of the vessel.

PIGMENT USE AND LOCATION ON VESSEL: none

TYPE AND VARIETY (IF KNOWN): Unidentified brushed utility ware, possibly Bullard Brushed

SITE NAME OR SITE NUMBER: 41HS74

VESSEL NO.: Lot 1607, Burial 4

VESSEL FORM: miniature Compound bowl

NON-PLASTICS AND PASTE: grog

RIM AND LIP FORM: Direct rim and rounded lip

CORE COLOR: A (fired and cooled in an oxidizing environment)

INTERIOR SURFACE COLOR: yellowish-brown

EXTERIOR SURFACE COLOR: yellowish-brown; fire clouds on the base

WALL THICKNESS (IN MM): rim, $4.0 \mathrm{~mm}$

INTERIOR SURFACE TREATMENT: none

EXTERIOR SURFACE TREATMENT: none

HEIGHT (IN CM): 5.0

ORIFICE DIAMETER (IN CM): 6.5

DIAMETER AT BOTTOM OF RIM OR NECK (IN CM): 6.7

BASE DIAMETER (IN CM) AND SHAPE OF BASE: 4.1; circular-rounded 
ESTIMATED VOLUME (IN LITERS): 0.26

DECORATION (INCLUDING MOTIF AND ELEMENTS WHEN APPARENT): Plain

PIGMENT USE AND LOCATION ON VESSEL: none

TYPE AND VARIETY (IF KNOWN): Unidentified plain ware

SITE NAME OR SITE NUMBER: 41HS74

VESSEL NO.: Lot 1608, Burial 4

VESSEL FORM: Carinated bowl

NON-PLASTICS AND PASTE: grog

RIM AND LIP FORM: Direct rim and rounded lip

CORE COLOR: $\mathrm{F}$ (fired in a reducing environment and cooled in the open air)

INTERIOR SURFACE COLOR: reddish-brown; fire clouds on the base

EXTERIOR SURFACE COLOR: reddish-brown; fire clouds on the body and base

WALL THICKNESS (IN MM): rim, $6.1 \mathrm{~mm}$; body, $7.9 \mathrm{~mm}$; base, $11.3 \mathrm{~mm}$

INTERIOR SURFACE TREATMENT: none

EXTERIOR SURFACE TREATMENT: smoothed

HEIGHT (IN CM): 5.1

ORIFICE DIAMETER (IN CM): N/A

DIAMETER AT BOTTOM OF RIM OR NECK (IN CM): N/A

BASE DIAMETER (IN CM) AND SHAPE OF BASE: 10.7; circular and flat

ESTIMATED VOLUME (IN LITERS): N/A

DECORATION (INCLUDING MOTIF AND ELEMENTS WHEN APPARENT): Plain

PIGMENT USE AND LOCATION ON VESSEL: none

TYPE AND VARIETY (IF KNOWN): Unidentified plain ware

SITE NAME OR SITE NUMBER: 41HS74

VESSEL NO.: Lot 1609, Burial 5

VESSEL FORM: Jar 
NON-PLASTICS AND PASTE: grog

RIM AND LIP FORM: Direct rim and rounded lip

CORE COLOR: $\mathrm{F}$ (fired in a reducing environment and cooled in the open air)

INTERIOR SURFACE COLOR: yellowish-brown

EXTERIOR SURFACE COLOR: yellowish-brown; fire clouds on the body

WALL THICKNESS (IN MM): rim, $5.6 \mathrm{~mm}$; body, $7.0 \mathrm{~mm}$

INTERIOR SURFACE TREATMENT: none

EXTERIOR SURFACE TREATMENT: smoothed

HEIGHT (IN CM): 8.2+

ORIFICE DIAMETER (IN CM): 9.0

DIAMETER AT BOTTOM OF RIM OR NECK (IN CM): 9.0

BASE DIAMETER (IN CM) AND SHAPE OF BASE: N/A

ESTIMATED VOLUME (IN LITERS): N/A

DECORATION (INCLUDING MOTIF AND ELEMENTS WHEN APPARENT): Plain

PIGMENT USE AND LOCATION ON VESSEL: none

TYPE AND VARIETY (IF KNOWN): Unidentified plain ware

SITE NAME OR SITE NUMBER: 41HS74

VESSEL NO.: Lot 1610, Burial 5

VESSEL FORM: Carinated bowl

NON-PLASTICS AND PASTE: bone

RIM AND LIP FORM: Direct rim and flat lip

CORE COLOR: F (fired in a reducing environment and cooled in the open air)

INTERIOR SURFACE COLOR: reddish-brown

EXTERIOR SURFACE COLOR: reddish-brown; fire clouds on the body and base

WALL THICKNESS (IN MM): rim, $5.6 \mathrm{~mm}$

INTERIOR SURFACE TREATMENT: none

EXTERIOR SURFACE TREATMENT: smoothed 
HEIGHT (IN CM): 4.8

ORIFICE DIAMETER (IN CM): 12.5

DIAMETER AT BOTTOM OF RIM OR NECK (IN CM): 12.5

BASE DIAMETER (IN CM) AND SHAPE OF BASE: 6.3; circular and flat

ESTIMATED VOLUME (IN LITERS): 0.36

DECORATION (INCLUDING MOTIF AND ELEMENTS WHEN APPARENT): Plain

PIGMENT USE AND LOCATION ON VESSEL: none

TYPE AND VARIETY (IF KNOWN): Unidentified plain ware

SITE NAME OR SITE NUMBER: 41HS74

VESSEL NO.: Lot 1611, Burial 7

VESSEL FORM: Bowl

NON-PLASTICS AND PASTE: grog-bone

RIM AND LIP FORM: Direct rim and rounded lip

CORE COLOR: B (fired and cooled in a reducing environment)

INTERIOR SURFACE COLOR: gray

EXTERIOR SURFACE COLOR: gray; fire clouds on the body and base

WALL THICKNESS (IN MM): rim, $6.0 \mathrm{~mm}$

INTERIOR SURFACE TREATMENT: none

EXTERIOR SURFACE TREATMENT: none

HEIGHT (IN CM): 6.3

ORIFICE DIAMETER (IN CM): 14.1

DIAMETER AT BOTTOM OF RIM OR NECK (IN CM): N/A

BASE DIAMETER (IN CM) AND SHAPE OF BASE: 6.4; circular and flat

ESTIMATED VOLUME (IN LITERS): 0.36

DECORATION (INCLUDING MOTIF AND ELEMENTS WHEN APPARENT): Plain PIGMENT USE AND LOCATION ON VESSEL: none

TYPE AND VARIETY (IF KNOWN): Unidentified plain ware 
SITE NAME OR SITE NUMBER: 41HS74

VESSEL NO.: Lot 1612, Burial 7

VESSEL FORM: Jar

NON-PLASTICS AND PASTE: grog

RIM AND LIP FORM: Direct rim and rounded lip

CORE COLOR: B (fired and cooled in a reducing environment)

INTERIOR SURFACE COLOR: dark grayish-brown

EXTERIOR SURFACE COLOR: dark grayish-brown; fire clouds on the rim and body

WALL THICKNESS (IN MM): rim, $6.3 \mathrm{~mm}$; body, $7.2 \mathrm{~mm}$

INTERIOR SURFACE TREATMENT: none

EXTERIOR SURFACE TREATMENT: none

HEIGHT (IN CM): 14.8

ORIFICE DIAMETER (IN CM): 12.3

DIAMETER AT BOTTOM OF RIM OR NECK (IN CM): 12.3

BASE DIAMETER (IN CM) AND SHAPE OF BASE: M/A

ESTIMATED VOLUME (IN LITERS): 1.1

DECORATION (INCLUDING MOTIF AND ELEMENTS WHEN APPARENT): The vessel rim has four sets of diagonal incised lines pitched in opposite directions, forming incised triangles filled with rows of tool punctations (Figure 8). The vessel body has rows of tool punctations that extend from the rim-body juncture to within $34 \mathrm{~mm}$ of the base.

PIGMENT USE AND LOCATION ON VESSEL: none

TYPE AND VARIETY (IF KNOWN): Unidentified incised-punctated, likely Maydelle Incised

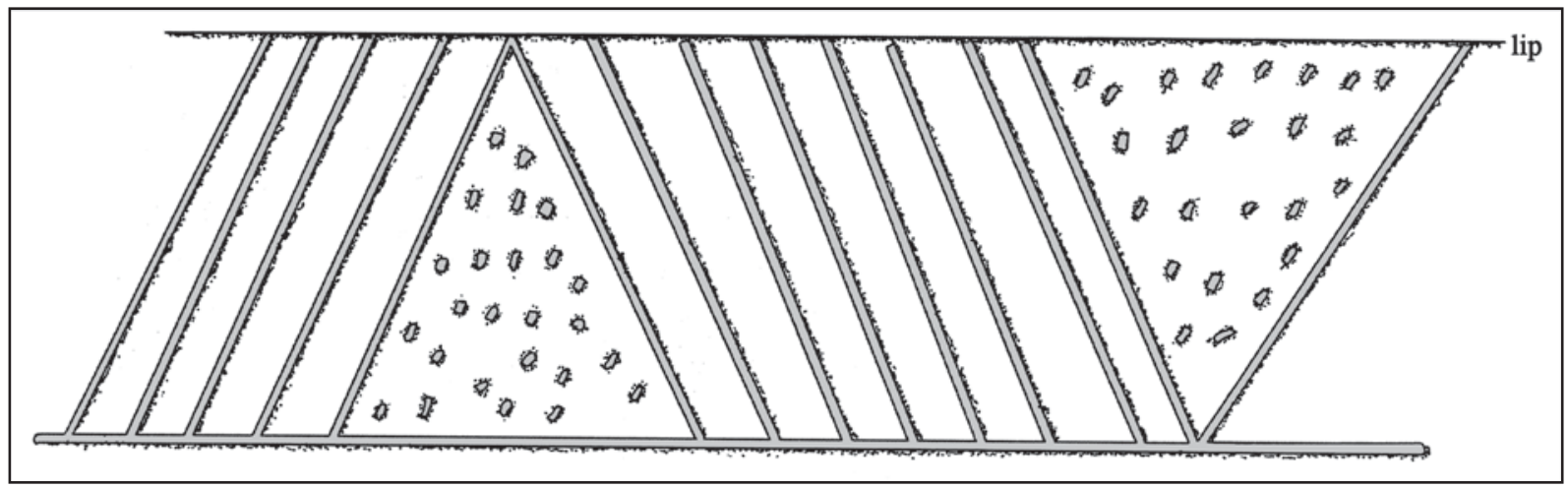

Figure 8. Decorative elements on the rim of Lot 1612 vessel, Burial 7 at $41 \mathrm{HS} 74$. 
SITE NAME OR SITE NUMBER: 41HS74

VESSEL NO.: Lot 1614, Burial 8

VESSEL FORM: Bottle

NON-PLASTICS AND PASTE: grog

RIM AND LIP FORM: Direct rim and rounded lip

CORE COLOR: $\mathrm{G}$ (fired in a reducing environment and cooled in the open air)

INTERIOR SURFACE COLOR: grayishbrown

EXTERIOR SURFACE COLOR:

yellowish-brown; fire clouds on the rim and base

WALL THICKNESS (IN MM): neck, 7.0 $\mathrm{mm}$

INTERIOR SURFACE TREATMENT: none

EXTERIOR SURFACE TREATMENT: none

HEIGHT (IN CM): 17.4

ORIFICE DIAMETER (IN CM): 4.2

DIAMETER AT BOTTOM OF RIM OR NECK (IN CM): 5.8

BASE DIAMETER (IN CM) AND SHAPE OF BASE: 7.6; circular and rounded

ESTIMATED VOLUME (IN LITERS): 0.53

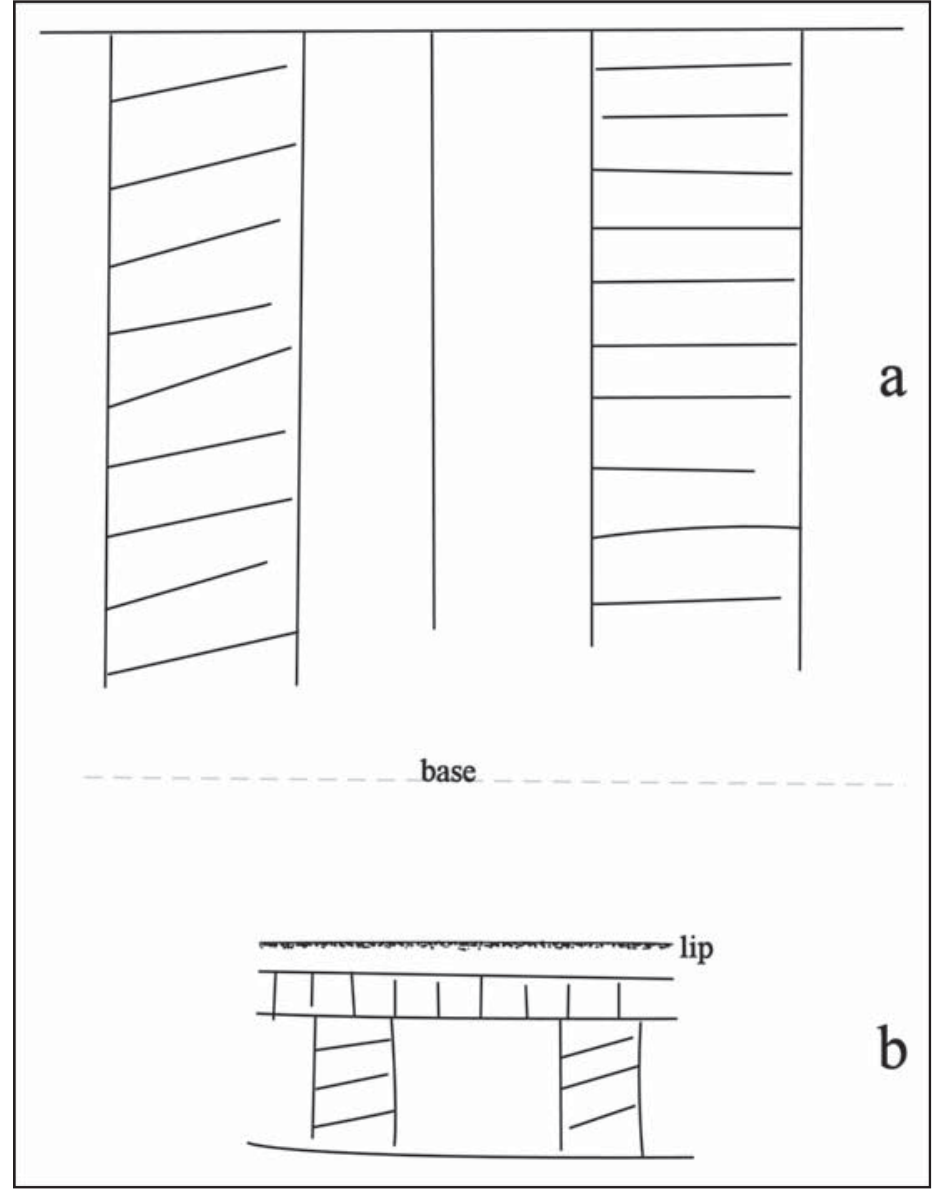

Figure 9. Decorative elements on the Lot 1614 bottle in Burial 8 at 41HS74: a, vessel body; b, vessel neck.

\section{DECORATION (INCLUDING MOTIF} AND ELEMENTS WHEN APPARENT):

The vessel body has nine sets of vertical engraved panels that are filled with either horizontal or diagonal hatched lines (Figure 9a). The upper part of the bottle neck has a narrow horizontal engraved zone filled with vertical hatched lines, and this zone sits atop a set of 12 individual vertical panels filled with diagonal hatched lines (Figure 9b).

PIGMENT USE AND LOCATION ON VESSEL: none

TYPE AND VARIETY (IF KNOWN): Unidentified fine ware 
SITE NAME OR SITE NUMBER: 41HS74

VESSEL NO.: Lot 1615, Burial 9

VESSEL FORM: Jar with scalloped rim and rim peaks

NON-PLASTICS AND PASTE: grog

RIM AND LIP FORM: Direct rim and rounded lip

CORE COLOR: $\mathrm{H}$ (fired in a reducing environment and cooled in the open air)

INTERIOR SURFACE COLOR: brownish-red; fire clouds on the rim

EXTERIOR SURFACE COLOR: very dark grayish-brown; fire clouds on the rim, body, and base; organic residue on the rim and body

WALL THICKNESS (IN MM): rim, 7.4 $\mathrm{mm}$

INTERIOR SURFACE TREATMENT: none

EXTERIOR SURFACE TREATMENT: none

HEIGHT (IN CM): $12.7 ; 13.9 \mathrm{~cm}$ at the rim peaks

ORIFICE DIAMETER (IN CM): 11.4

DIAMETER AT BOTTOM OF RIM OR NECK (IN CM): 11.4

BASE DIAMETER (IN CM) AND SHAPE OF BASE: 6.8; circular and flat

ESTIMATED VOLUME (IN LITERS): 0.87

DECORATION (INCLUDING MOTIF

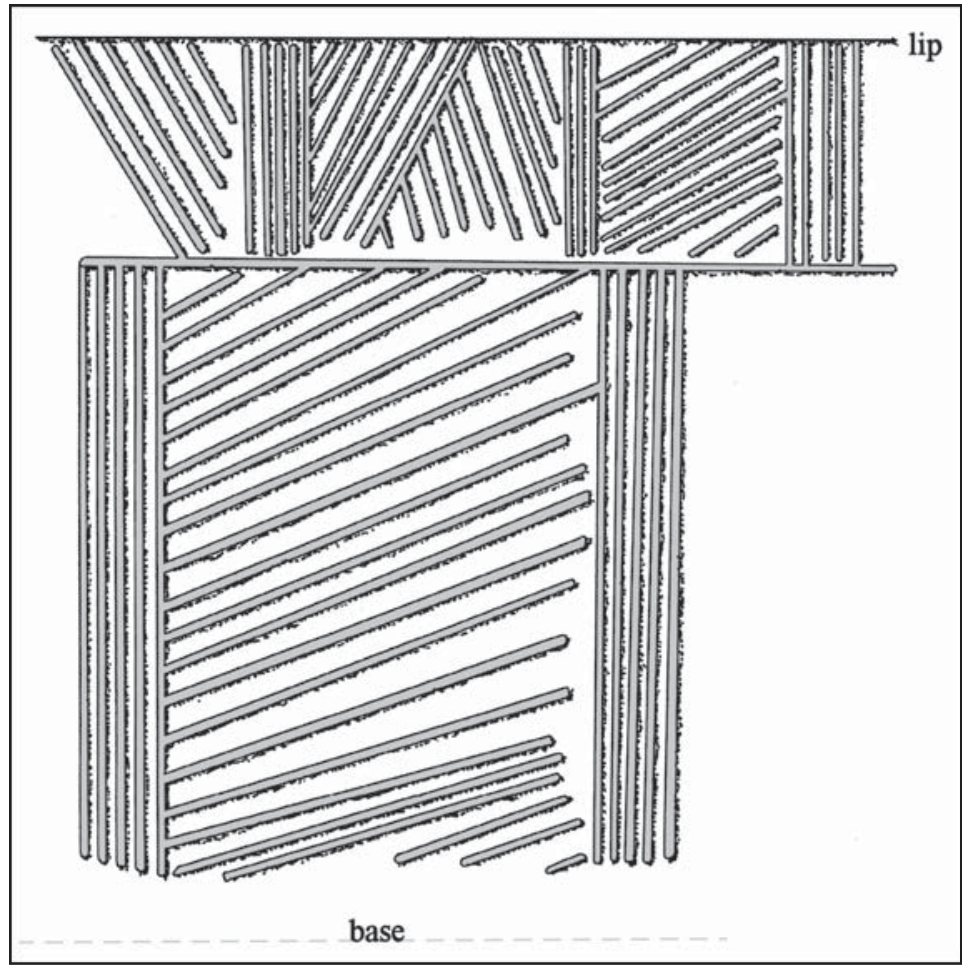

Figure 10. Decorative elements on Lot 1615 vessel in Burial 9 at $41 \mathrm{HS} 74$. AND ELEMENTS WHEN APPARENT):

The vessel rim has a set of five vertical incised panels (defined by a series of closely-spaced vertical incised lines) filled with closely-spaced diagonal incised lines pitched in opposite directions (Figure 10). There is a single broad horizontal incised line at the rim-body juncture. The vessel body has eight vertical incised panels defined by sets of closely-spaced vertical incised lines. Each of the panels is filled with closely-spaced diagonal incised lines pitched in opposite directions.

PIGMENT USE AND LOCATION ON VESSEL: none

TYPE AND VARIETY (IF KNOWN): cf. Dunkin Incised (see Suhm and Jelks 1962:Plate 19) 
SITE NAME OR SITE NUMBER: 41HS74

VESSEL NO.: Lot 1616, Burial 9

VESSEL FORM: Carinated bowl

NON-PLASTICS AND PASTE: grog

RIM AND LIP FORM: Direct rim and rounded lip

CORE COLOR: F (fired in a reducing environment and cooled in the open air)

INTERIOR SURFACE COLOR: yellowish-brown; fire clouds on the rim, body, and base

EXTERIOR SURFACE COLOR: yellowish-brown; fire clouds on the body and base

WALL THICKNESS (IN MM): rim, $6.2 \mathrm{~mm}$

INTERIOR SURFACE TREATMENT: none

EXTERIOR SURFACE TREATMENT: smoothed

HEIGHT (IN CM): 7.6

ORIFICE DIAMETER (IN CM): 15.0

DIAMETER AT BOTTOM OF RIM OR NECK (IN CM): 15.0

BASE DIAMETER (IN CM) AND SHAPE OF BASE: 7.4; circular and flat

ESTIMATED VOLUME (IN LITERS): 0.68

DECORATION (INCLUDING MOTIF AND ELEMENTS WHEN APPARENT): Four widely-spaced horizontal engraved lines on the vessel rim.

PIGMENT USE AND LOCATION ON VESSEL: none

TYPE AND VARIETY (IF KNOWN): Hickory Engraved

\section{Summary and Conclusions}

1980s excavations at 41HS74 in the mid-Sabine River basin by Heartfield, Price and Greene, Inc. (1988) identified nine ancestral Caddo burial features in a small cemetery. Each of the burial features had associated Caddo ceramic vessels as funerary offerings, with a range of 1-4 vessels per burial. The 23 remaining ceramic vessels from the site in the collections at the Texas Archeological Research Laboratory have been reanalyzed to better ascertain the temporal and functional characteristics of this distinctive East Texas ceramic assemblage.

Several different vessel forms, mainly small to medium-sized based on their estimated volume in liters, are present in the 41HS74 vessel assemblage, principally jars (30.4 percent) and carinated bowls (26.1 percent). Other vessel forms include compound bowls (13.0 percent), bowls (13.0 percent), and 
bottles ( 8.7 percent); one incomplete vessel in Burial 1 may be from a bowl or carinated bowl. These vessels were uniformly manufactured with grog ( 87.1 percent), followed by bone ( 8.6 percent); one vessel (4.3 percent) was tempered with both grog and bone.

Nine of the 23 vessels (39.1 percent) in the 41HS74 vessel assemblage are plain. This includes one bottle, one bowl or carinated bowl, two jars, one bowl, three carinated bowls, and one compound bowl. Of the 14 vessels with decorative elements, 35.7 percent $(n=5)$ are fine wares with engraved or excised designs, and the remaining 64.3 percent of the vessels $(n=9)$ have wet paste utility ware decorative elements, including: brushed-punctated $(n=1)$, incised $(n=2)$, punctated-appliqued $(n=1)$, incisedpunctated $(n=3)$, appliqued/noded $(n=1)$, and brushed $(n=1)$.

Vessels that can be identified to a currently defined Caddo ceramic type include: Pease BrushedIncised and Maydelle Incised jars in Burial 1; a Handy Engraved carinated bowl and a Crockett Curvilinear Incised compound bowl in Burial 2; a Moore Noded bowl in Burial 3; and a Dunkin Incised jar and a Hickory Engraved carinated bowl in Burial 9. The range in identified decorative ceramic types in the 41HS74 vessel assemblage suggests that the cemetery began to be used sometime in the Early Caddo period (ca. A.D. 1000-1200) with the interment of Burial 9. Based on the recovered ceramic vessel types, and the arranged placement of burials in rows in the cemetery (see Figure 2b), the other burials likely were all interred after ca. A.D. 1200, in the Middle Caddo period. Certainly, Pease Brushed-Incised, Handy Engraved, and Maydelle Incised vessels would not be out of place in an East Texas cemetery dating to this period, nor would an engraved bottle with decorative elements suggestive of snake elements (Lot 1605 bottle in Burial 4). Burial 3, with the Moore Noded bowl and the incisedpunctated carinated bowl, may be the latest interment in the cemetery.

The one available radiocarbon date from the 41HS74 cemetery is on a charcoal sample near the cranium of Burial 1, and confirms the Middle Caddo period age of one of the burials; unfortunately the standard deviation of the sample is very broad. The conventional age of the sample is $630 \pm 240$ years B.P., with a mean age of A.D. 1320 (Heartfield, Price and Greene, Inc. 1988:13-1). The IntCal13 calibrated mean age of this sample is 565 years B.P., or A.D. 1385. Clearly, more radiocarbon dates are needed from the cemetery to truly establish its likely period or periods of use by ancestral Caddo peoples.

In conclusion, the cemetery at 41HS74 was used, probably episodically, during what was likely the end of the Early Caddo period through the latter part of the $14^{\text {th }}$ century A.D., during the Middle Caddo period. The settlement of this site, and the interment of burials in a small cemetery there, primarily predated the establishment of the Pine Tree Mound site (41HS15) and associated community (see Fields and Gadus 2012b:638) in the same part of the mid-Sabine River basin in East Texas.

\section{Acknowledgments}

Thanks to Marybeth Tomka for providing access to the vessel collections from 41HS74 at the Texas Archeological Research Laboratory, The University of Texas at Austin. Lance Trask prepared the figures in this article.

\section{References Cited}

Fields, R. C. and E. F. Gadus

2012a The Pine Tree Mound Site and the Archeology of the Nadaco Caddo. Bulletin of the Texas Archeological Society 83:23-80.

Fields, R. C. and E. F. Gadus (editors)

2012b Archeology of the Nadaco Caddo: The View from the Pine Tree Mound Site (41HS15), Harrison County, Texas. 2 Vols. Reports of Investigations No. 164. Prewitt and Associates, Inc., Austin. 
Hart, J. P.

2014 An Analysis of the Aboriginal Ceramics from the Washington Square Mound Site, Nacogdoches County, Texas. Stephen F. Austin State University Press, Nacogdoches.

Hart, J. P. and T. K. Perttula

2010 The Washington Square Mound Site and a Southeastern Ceremonial Complex Style Zone among the Caddo of Northeastern Texas. Midcontinental Journal of Archaeology 35(2):199-228.

Heartfield, Price, and Greene, Inc.

1988 Data Recovery at 41HS74, Harrison County, Texas. Heartfield, Price, and Greene, Inc., Monroe.

Suhm, D. A. and E. B. Jelks (editors)

1962 Handbook of Texas Archeology: Type Descriptions. Special Publication No. 1, Texas Archeological Society, and Bulletin No. 4, Texas Memorial Museum, Austin. Reprinted in 2009, Gustav's Library, Davenport, Iowa.

Walters, $\mathrm{M}$.

2006 The Lake Clear (41SM243) Site and Crotalus horridus atricaudatus. Caddoan Archeology Journal 15:541 .

Webb, C. H.

1959 The Belcher Mound, a Stratified Caddoan Site in Caddo Parish, Louisiana. Memoirs No. 16. Society for American Archaeology, Salt Lake City. 